\title{
GOODWILL AND ITS EFFECT ON SHARE PRICE OF MANUFACTURING AND NONMANUFACTURING COMPANIES
}

\author{
Martin Kedron ${ }^{1}$ \\ ${ }^{1}$ Department of Accounting and Taxes, Faculty of Business and Economics, Mendel University in Brno, \\ Zemědělská 1, 61300 Brno, Czech Republic
}

Link to this article: https://doi.org/10.11118/actaun202068020373

Received: 31. 12. 2019, Accepted: 6. 3. 2020

To cite this article: KEDRON MARTIN. 2020. Goodwill and Its Effect on Share Price of Manufacturing and Nonmanufacturing Companies. Acta Universitatis Agriculturae et Silviculturae Mendelianae Brunensis, 68(2): 373-381.

\begin{abstract}
This research examines how goodwill is relevant to share price on a sample of European companies with goodwill. The dataset includes 7,253 European companies broken down by sector according to the NACE classification in the period 2009-2017. Linear regression analysis was used to identify the effect of goodwill on share price. It was found out that goodwill has a positive effect on share price in manufacturing companies. These results suggest that the information contained in goodwill should be more identified to provide users of reporting with more information.
\end{abstract}

Keywords: primary goodwill, secondary goodwill, intangible assets, sectors of intangible assets

\section{INTRODUCTION}

This research aims to determine an association between goodwill and share price and to confirm or refute the effect of this variable. The results of this research will be the basis for researching unidentifiable intangible assets and their recognising and reporting. The aim of the main research underlying this paper is to identify the variables that affect the stock price and subsequently the goodwill of listed companies. Future research will address the transfer these identifiers to unlisted companies and recommend methods to identify and recognize so far unreported intangible assets, which are currently recorded in goodwill.

In the $21^{\text {st }}$ century, all businesses around the world are facing increasing competition, accelerated economic globalization and the development of a knowledge-based economy. Therefore, intangible assets play an increasingly important role in gaining competitive advantages (Xingxi, 2017).
More detailed reporting of the company's assets increases the importance of intangible assets. Ciprian (2012) stated in his research that intangible assets accounted for 5\% of total assets in 1978, in 1998 intangible assets accounted for $72 \%$ of total assets, and currently they account for $75-85 \%$ of total assets.

In many OECD countries, investments in intangible assets are growing rapidly. In some cases, these investments correspond to or exceed investments in traditional capital such as machinery, equipment and buildings. Increased global competition, information and communication technologies, new business models and the growing importance of the service sector have resulted in the strengthening of intangible assets in companies, industries and national economies (OECD, 2011). In this context, companies are entering a period in which intangible assets are an important asset in the company (Marilei, 2017).

Intangible assets are recorded under the current methodology mostly as software and know- 
how. However, the scope of intangible assets is much broader. There are different theories about what is an intangible asset that can be identified, categorized and valued. For example, the 2011 OECD study groups intangible items into three types: computer information (software and databases), pioneering assets (scientific and nonscientific R\&D, copyrights, projects, trademarks), and economic competencies (trademarks, corporate human capital, business communication systems, organizational know-how that increases business efficiency, and advertising and marketing aspects).

If companies have intangible assets that are difficult to record, pricing models are required for these assets. Intangible assets which are accounted for and reported are defined but the enterprise may also have some other intangible economic resources that are not available under current reporting methods. An example of such intangible assets is knowledge capital, which is not currently reflected in the financial statements. This knowledge capital includes the knowledge, experience and intellectual strength of employees and the knowledge stored in organizational databases, systems, processes, culture and philosophy. This knowledge capital is managed and used to obtain services and products with the ultimate goal of generating revenue (Ciprian, 2012).

Historically, intangible assets are valued using traditional valuation approaches: costs, revenues and market values. Different approaches applied to the same intangible asset may result in very different values. The cost approach may be useful, but is rarely definitive as value is closely linked to future benefits. The market approach is attractive to businesses, but to be effective it should be based on a reasonable number of meaningful transactions. However, this data is sometimes not available (Mercer, 2002).

Lack of information and rules on the definition, measurement and reporting of intangible assets makes it difficult for investors and creditors to measure the intangible value of the company before making relevant decisions on investments and loans (Tsai, Lu, Hung, 2016).

In the case of goodwill accounting, it is worth considering the possibility that investors and other users of financial statements might in fact regard goodwill numbers as a useful, although imperfect, indicator of the intangible asset of the company's value.

In terms of intangibles, the accounting profession restricts asset valuation and recognition to items which are clearly identifiable such as copyrights, licensing agreements, patents, trademarks, trade names, and so on. Other intangible assets such as an honourable business reputation, good customer relations, unique market position, a well-trained workforce, or the value of brand names have generally been deemed too insubstantial to warrant recognition. This is despite the fact that tremendous economic value is obvious for such brand names as Coca-Cola, Gillette, and Marlboro (Chauvin, 1994).

\section{Literature Review}

In a business acquisition or merger, an entity needs to measure and recognize the acquired entity in the financial statements of the new company in accordance with accounting standards. As part of consolidation, a newly created entity is required to allocate the purchase price into tangible and identifiable intangible assets and liabilities acquired by the enterprise through acquisition or merger (Bugeja, 2015).

Business combinations are measured in accounting at fair value. Acquiring companies report acquired assets and liabilities assumed, including identifiable intangible assets, at their estimated fair value. Goodwill is the remainder of the fair value of the consideration reduced by the fair value of the identifiable net assets acquired. Measuring fair values of identifiable intangible assets is often difficult (Bauman, 2018).

Perhaps the most serious measurement concern with accounting goodwill numbers lies in the fact that goodwill is only recognized for accounting purposes in the case of a business acquisition. Accounting goodwill is only recognized when an entire business is purchased because it is a goingconcern valuation which cannot be allocated to specific assets or separated from the business as a whole (Chauvin, 1994).

In line with the difficulty in determining the fair values of identifiable intangible assets acquired, goodwill is usually a large proportion of the assets acquired in business combinations (Shalev, 2013).

Goodwill represents a significant part of the company's balance sheet and is therefore an important asset of the company (Jennings, 1996). Investors obtain information about goodwill to create an appropriate perception of the company's intangible assets. Goodwill is considered to be the most sensitive asset in an enterprise's impairment, as SFAS 142 requires a goodwill impairment test if there is a decrease in the company's value (Filip, 2015). Impairment of goodwill also reflects managerial inability to extract value from previous acquisitions by important events (Sun, 2016; Darrough, 2014).

Historically, goodwill is one of the long-discussed topics. There have been discussions about how to value and record goodwill in the books since the $19^{\text {th }}$ century, and it is no different today. It is very difficult to determine how to define, quantify, recognize or value goodwill, and there is some variability and inconsistency regarding the ideal valuation of goodwill (Zelenka, 2006).

Goodwill can be divided into two basic units primary and secondary goodwill. The primary goodwill is goodwill that was not part of the acquired 
business unit. This means that it is not goodwill that arises from a business combination, but goodwill that an entity had to create by its own skills and synergies between individual departments. This kind of goodwill is not yet recognized by the accounting system. According to Zelenka, primary goodwill can be divided into two basic categories, namely goodwill created by the company and goodwill from favourable exogenous circumstances. The category of goodwill generated by the enterprise includes components that are the result of the strategic efforts of each enterprise. Their basic feature is the pursuit of continuous development, the ability to create superior performance and their distinguishability from the competition. It is a way of working and an in-house system. Goodwill created by the company includes employee qualifications, advertising and company image, innovation, research and development, competitive market position, business perspective and growth. In the category of goodwill from exogenous circumstances there are external phenomena that have a positive effect on the company, phenomena that contribute to its prosperity, and phenomena that create a comparative advantage in the market. Favourable external circumstances affect the company from the territorial and demographic point of view, but there is also the effect of the tradition of the industry in the field. The secondary goodwill can be described as goodwill that was already part of the entity or arose from a business combination, i.e. an acquisition between two companies. This type of goodwill is recognized on completion of the business acquisition, including its quantification. It is typical of secondary goodwill that its acquisition is accompanied by a higher amount of cost (Zelenka, 2006).

Secondary goodwill of the acquired entity may already have a portion of primary goodwill. This means goodwill generated from the entity's own resources and goodwill arising from exogenous circumstances. This fact is reflected in the price of the acquired unit. Primary goodwill is transformed during a business combination and moves at least partially to a group of secondary goodwill and thereby increases or theoretically decreases the difference between the price of the acquired entity and the price of assets owned by this entity (Zelenka, 2006).

\section{MATERIALS AND METHODS}

For this study a database was created of all listed companies with goodwill in all markets in 20092017. Data were collected from the Orbis database. Since there are more methods of reporting (IFRS, US GAAP) and determining goodwill values, it is necessary to classify these companies. According to geographic location the companies analyzed were from Europe, North America, South America, Africa, Asia and Oceania. To fulfill the objectives of the paper, the European market was selected, which contains 7,253 companies out of a total of 22,000 companies. All of these companies report under IFRS. Since 2005 it has been required in Europe to report under IFRS for listed companies so that economic indicators are comparable to other entities in the market. The results on the European market were compared with the findings of Keit (1994), which showed that goodwill had a significant effect on the price of the listed companies in the US market.

Extreme 5\% quantile values were removed from the database to reduce bias. More details of this are given in Annex Tab. VII.

In this paper, the relationship between individual factors and share price was investigated. For this reason, a method of regression analysis of panel data with an OLS estimator and fixed effects was chosen.

The empirical model used in this paper is developed from a basic model that governs the theoretical determinants of equity value identified by Feltham and Ohlson (1995). This model was used in the previous empirical research (e.g. Amir, 1997; Bauman, 2016; Laux, 2013). The Feltham-Ohlson model is expressed as:

$$
\begin{aligned}
\text { Price }_{t}= & \beta_{0}+\beta_{1} N O A_{t}+\beta_{2} N F A_{t}+\beta_{3} A E_{t}+\beta_{4} \operatorname{lag} A E_{t}+ \\
& + \text { Year }_{t}+\operatorname{Ind}_{t}+\varepsilon_{t},
\end{aligned}
$$

where PRICE is a share price, NOA is a net operating asset, NFA is a net financial asset, AE is an unusual profit, and lag AE is an AE delayed by one year. The model also includes effects with fixed time (year $t$ ) and industry (Ind $j$ ).

For research described in this article the FelthamOhlson model was modified and expressed as follows:

$Y_{i t}=a_{i t}+\beta_{1} X_{1 i t}+\beta_{2} X_{2 i t}+\beta_{3} X_{3 i t}+\beta_{4} X_{4 i t}+\beta_{5} X_{5 i t}+\beta_{6} X_{6 i t}+\varepsilon_{i}$,

where $Y$ is price per share for the ith company at time $t, a$ shows the constant, the variable $x 1$ it is goodwill for the ith company at time $t$, $x 2$ it is the NFA for the ith company at time $t, x 3 i t$ is the NOA for the ith company at time $t, x 4 i t$ is R \& D for the ith company at time $t$, $x 5$ it is ROA for the ith company at time $t$, x6it is ROE for the ith company at time $t$, beta coefficients 1, 2, 3, 4, 5 and 6 determine the link between variable and share price, the last member of the equation is the wrong member of the model.

Selected variables are based on research on goodwill and its impact on the market value of a share similar to that of Bauman (2018) and Sun (2016).

Tab. I summarizes a sample of European companies broken down into groups by the NACE classification. Data are adjusted for extremes (5\%) - see Tab. VII. The highest representation is in the C sector - Manufacturing with 1,150 companies (24,795 observations). Other sectors are included in the group of non-manufacturing companies. All 
I: Breakdown by company according to the NACE

\begin{tabular}{lccc}
\hline \multicolumn{1}{c}{ NACE section } & Obs & Percent & Cum. \\
\hline A - Agriculture, forestry and fishing & 780.00 & 1.19 & 1.19 \\
B - Mining and quarrying & 1,935 & 2.96 & 4.16 \\
C - Manufacturing & 24,795 & 37.96 & 42.11 \\
D - Electricity, gas, steam and air conditioning supply & 1,845 & 2.82 & 44.94 \\
E - Water supply; sewerage, waste & 405.00 & 0.62 & 45.56 \\
F - Construction & 2,145 & 3.28 & 48.84 \\
G - Wholesale and retail trade & 5,835 & 8.93 & 57.77 \\
H - Transportation and storage & 1,830 & 2.80 & 60.57 \\
I - Accommodation and food service activities & 900.00 & 1.38 & 61.95 \\
\hline J - Information and communication & 9,180 & 14.05 & 76.00 \\
K - Financial and insurance activities & 3,765 & 5.76 & 81.77 \\
\hline L - Real estate activities & 2,415 & 3.70 & 85.46 \\
M - Professional, scientific and technical activities & 4,125 & 6.31 & 91.78 \\
\hline N - Administrative and support service activities & 2,130 & 3.26 & 95.04 \\
\hline O - Public administration and defence & 180.00 & 0.28 & 95.32 \\
P - Education & 210.00 & 0.32 & 95.64 \\
Q - Human health and social work activities & 1,080 & 1.65 & 97.29 \\
R - Arts, entertainment and recreation & 1,005 & 1.54 & 98.83 \\
\hline S - Other service activities & 765.00 & 1.17 & 100.00 \\
\hline Total & 65,325 & 100.00 & \\
\hline
\end{tabular}

II: Descriptive statistics

\begin{tabular}{lccccc}
\hline \multicolumn{1}{c}{ Variable } & Obs & Mean & Std. Dev. & Min & Max \\
\hline Price & 27,635 & 1.82 & 1.36 & 0.18 & 6.89 \\
Goodwill & 26,012 & 0.91 & 1.90 & 0.00 & 11.23 \\
NFA & 29,629 & -1.25 & 2.49 & -14.25 & 0.64 \\
NOA & 25,170 & 8.51 & 16.06 & 0.02 & 93.59 \\
R \& D & 30,730 & -0.03 & 0.09 & -0.64 & 0.00 \\
ROA & 33,150 & -14.18 & 1125.20 & -199750.40 & 4713.33 \\
ROE & 33,110 & -35.02 & 2782.52 & -327866.70 & 123000.00 \\
\hline
\end{tabular}

sectors were used for the research. Some studies exclude non-manufacturing sectors, e.g. the Bauman (2018) research excluded the public services, finance and real estate (SIC code) research. The largest representation of non-manufacturing sectors is Information and communication, Wholesale and retail trade, Financial and insurance activities and Professional, scientific and technical activities. No sectors were excluded from the research.

Tab. II provides descriptive statistics for all variables used in regression analyses. Variables are measured on a per share basis. Badwill is not included for the goodwill variable after cleaning. Annex Tab. VII shows the results before and after cleaning the dataset.
Tab. III shows the correlation relationship between variables in the model. The share price is positively correlated with goodwill, NOA and ROA, as confirmed by Bauman (2018) research. There is no multicollinarity in correlation.

The OLS method will be used as a fixed effects model. This is because companies are considered heterogeneous and must be sought separately. Tab. IV shows the results of the Hausman test.

\section{RESULTS}

The results show that all variables have a significant impact on the share price. Model 2 in Tab. V presents estimates of coefficients from robust 
III: The correlation coefficient

\begin{tabular}{|c|c|c|c|c|c|c|c|}
\hline & Price & Goodwill & NFA & NOA & $\mathrm{R} \& \mathrm{D}$ & ROA & ROE \\
\hline Price & 1 & & & & & & \\
\hline Goodwill & 0.1221 & 1 & & & & & \\
\hline NFA & -0.0368 & -0.5211 & 1 & & & & \\
\hline NOA & 0.0551 & 0.5380 & -0.6405 & 1 & & & \\
\hline$R \& D$ & -0.1098 & -0.2066 & 0.1734 & -0.1229 & 1 & & \\
\hline ROA & 0.0123 & 0.0062 & -0.0079 & 0.0667 & -0.0046 & 1 & \\
\hline ROE & -0.0030 & 0.0071 & -0.0072 & 0.0067 & -0.0046 & 0.0037 & 1 \\
\hline
\end{tabular}

IV: The Hausman test

\begin{tabular}{lccc}
\hline & Fixed effects & Random effects & Difference \\
\hline Goodwill & 0.060694 & 0.100549 & -0.039855 \\
NFA & -0.019694 & -0.009692 & -0.010003 \\
NOA & -0.006626 & -0.013317 & 0.006691 \\
R\& D & -1.530313 & -1.418673 & -0.111640 \\
ROA & 0.011133 & 0.011108 & 0.000025 \\
ROE & -0.002461 & -0.002317 & -0.000144 \\
\hline
\end{tabular}

Test: Ho: difference in coefficients not systematic $\operatorname{chi}^{2}(3)=42.6$

Prob $>$ chi $^{2}=0$

regression. Robust estimates minimize the function of regression residues using weighted least squares, which results in parameter estimates that are less sensitive to extreme values of raw (untransformed) variables (Verardi, 2009). The coefficients in the calculation using the fixed effect estimate do not change much, compared to those calculated using robust analysis. According to the Hausman test, we use fixed effect estimates, in models 3 and 4, time effects were also included that reflect the evolution of time as they change with each other. Time effects show more accurate results. In the model we can see that the significance does not differ in individual variables.

The goodwill variable is positively significant in models (1). Previous research by Chauvin (1994), McCarthy (1995), Jennings (1996) and Henning (2000) shows a positive link between the reported goodwill balances (Bauman, 2018). This relationship was proved in the US securities market. The research also confirms that goodwill is significant for the share price of European companies. Also, research by Keith (1994) confirms the positive relationship between goodwill and market value. Net operating assets are also positively significant and in line with economic intuition and previous research.
R \& D costs are significant in the model, the relationship between R \& D expenditure and market value of equity is confirmed in research by Aboody (2000) on internally developed R \& D costs. The last significant variable in the model is the return on equity (ROE), which was used from research that examined the relationship between goodwill and equity. This variable is also positive in relation to the share price (Jennings, 1996; Li Sun, 2016).

In Tab. VI, companies are divided into manufacturing and non-manufacturing enterprises. Manufacturing enterprises are classified according to NACE in the category C - Manufacturing. Non-manufacturing enterprises include other companies according to Tab. I. In model 5, manufacturing companies which include 1,150 European companies are studied. Their share prices are positively influenced by the goodwill and return on assets (ROA) variable. Share prices are negatively influenced by NOA, R\&D costs and return on equity (ROE). When time effects are included in the model (models 7 and 8), it can be observed that in the non-manufacturing sector the effect of goodwill on the share price becomes insignificant. Thus, it becomes evident that it is necessary to select non-manufacturing enterprises by activity and to determine whether goodwill affects the share price in each non-manufacturing sector. 
V: Regression analysis - influence of variables on the share price

\begin{tabular}{|c|c|c|c|c|}
\hline \multirow{2}{*}{ VARIABLES } & (1) & $(2)$ & (3) & $(4)$ \\
\hline & Fixed effects & Robust effects & Fixed effects & Robust effects \\
\hline \multirow{2}{*}{ Goodwill } & $0.061^{* * *}$ & $0.101^{* * *}$ & $0.040^{* * *}$ & $0.083^{* * *}$ \\
\hline & $(0.014)$ & $(0.017)$ & $(0.014)$ & $(0.016)$ \\
\hline \multirow{2}{*}{ NFA } & $-0.020^{* *}$ & -0.010 & -0.013 & -0.008 \\
\hline & $(0.008)$ & $(0.008)$ & $(0.008)$ & $(0.008)$ \\
\hline \multirow{2}{*}{ NOA } & $-0.007^{* * *}$ & $-0.013^{* * *}$ & $-0.013^{* * *}$ & $-0.016^{* * *}$ \\
\hline & $(0.003)$ & $(0.002)$ & $(0.002)$ & $(0.002)$ \\
\hline \multirow{2}{*}{$R \& D$} & $-1.530 * * *$ & $-1.419 * * *$ & $-1.148^{* * *}$ & $-1.247^{* * *}$ \\
\hline & $(0.203)$ & $(0.250)$ & $(0.197)$ & $(0.237)$ \\
\hline \multirow{2}{*}{ ROA } & $0.011^{* * *}$ & $0.011^{* * *}$ & $0.011^{* * *}$ & $0.011^{* * *}$ \\
\hline & $(0.001)$ & $(0.002)$ & $(0.001)$ & $(0.002)$ \\
\hline \multirow{2}{*}{ ROE } & $-0.002^{* * *}$ & $-0.002^{* * *}$ & $-0.002^{* * *}$ & $-0.002^{* * *}$ \\
\hline & $(0.000)$ & $(0.000)$ & $(0.000)$ & $(0.000)$ \\
\hline \multirow{2}{*}{ Constant } & $0.624^{* * *}$ & $1.779^{* * *}$ & $0.015^{* * *}$ & $2.120^{* * *}$ \\
\hline & $(0.016)$ & $(0.027)$ & $(0.025)$ & $(0.036)$ \\
\hline Observations & 15,456 & 15,456 & 15,456 & 15,456 \\
\hline R-squared & 0.022 & & 0.093 & \\
\hline Number of firms & 2,906 & 2,906 & 2,906 & 2,906 \\
\hline Time effects & No & No & Yes & Yes \\
\hline \multicolumn{5}{|c|}{ Standard errors in parentheses ${ }^{* * *} \mathrm{p}<0.01,{ }^{* *} \mathrm{p}<0.05,{ }^{*} \mathrm{p}<0.1$} \\
\hline \multicolumn{5}{|c|}{ VI: Division by sectors - manufacturing, non-manufacturing } \\
\hline \multirow{2}{*}{ VARIABLES } & $(5)$ & $(6)$ & (7) & $(8)$ \\
\hline & Manufacturing & Non-manufacturing & Manufacturing & Non-manufacturing \\
\hline \multirow{2}{*}{ Goodwill } & $0.080^{* * *}$ & $0.046^{* *}$ & $0.052^{* *}$ & 0.030 \\
\hline & $(0.025)$ & $(0.019)$ & $(0.023)$ & $(0.019)$ \\
\hline \multirow{2}{*}{ NFA } & -0.019 & -0.017 & $-0.021^{*}$ & -0.007 \\
\hline & $(0.014)$ & $(0.011)$ & $(0.013)$ & $(0.011)$ \\
\hline \multirow{2}{*}{ NOA } & $-0.009^{*}$ & $-0.006^{*}$ & $-0.019 * * *$ & $-0.011^{* * *}$ \\
\hline & $(0.005)$ & $(0.003)$ & $(0.005)$ & $(0.003)$ \\
\hline \multirow{2}{*}{$\mathrm{R} \& \mathrm{D}$} & $-1.248^{* * *}$ & $-2.078^{* * *}$ & $-0.658^{* * *}$ & $-1.903^{* * *}$ \\
\hline & $(0.244)$ & $(0.372)$ & $(0.233)$ & $(0.363)$ \\
\hline \multirow{2}{*}{ ROA } & $0.015^{* * *}$ & $0.008^{* * *}$ & $0.014^{* * *}$ & $0.008^{* * *}$ \\
\hline & $(0.001)$ & $(0.001)$ & $(0.001)$ & $(0.001)$ \\
\hline \multirow{2}{*}{ ROE } & $-0.003^{* * *}$ & $-0.002^{* * *}$ & $-0.003^{* * *}$ & $-0.002^{* * *}$ \\
\hline & $(0.000)$ & $(0.000)$ & $(0.000)$ & $(0.000)$ \\
\hline \multirow{2}{*}{ Constant } & $1.587^{* * *}$ & $1.693^{* * *}$ & $2.099 * * *$ & $2.000^{* * *}$ \\
\hline & $(0.026)$ & $(0.022)$ & $(0.038)$ & $(0.036)$ \\
\hline Observations & 6,736 & 8,189 & 6,736 & 8,189 \\
\hline R-squared & 0.034 & 0.015 & 0.137 & 0.065 \\
\hline Number of firms & 1,150 & 1,653 & 1,150 & 1,653 \\
\hline Time effects & No & No & Yes & Yes \\
\hline
\end{tabular}

Standard errors in parentheses ${ }^{* * *} \mathrm{p}<0.01,{ }^{* *} \mathrm{p}<0.05,{ }^{*} \mathrm{p}<0.1$ 


\section{CONCLUSION}

This research provides empirical evidence of the significant positive effect of goodwill on the share price of listed European companies in the manufacturing sector. This significance demonstrates that goodwill is an important asset and that it is necessary to better identify it and improve its reporting. This positive correlation corresponds to research by Keit (1994), which reached the same conclusion for the US market. The results are comparable to the European and US markets, the effect of goodwill on the share price is demonstrable in manufacturing companies. In non-manufacturing sectors, significance is not evident, therefore these sectors need to be separated and significance needs to be determined for each sector.

In practice, these results could help determine when goodwill should be included in the pricing models for the manufacturing and non-manufacturing sectors, where it was shown that in the manufacturing sectors goodwill has a significant effect on the share price.

Since goodwill is the most sensitive asset that can lead to a decrease in the fair value of an enterprise, it is necessary to specify this asset more closely, as it is also confirmed in research by Bauman (2018). The Feltham-Ohlson regression model was modified in this research and variables from other research were applied to goodwill. The variables NOA, R\& D, ROA, and ROE were significant in the regression model used.

Given the importance of goodwill on the share price, as this research suggests, it is necessary for policy makers and national legislators to take greater account of this asset and thus devise methods to report goodwill more closely. Empirical studies suggest that reporting goodwill as a whole may lead to the loss of important information (Bauman, 2018).

This research provides a literary overview of goodwill and its detailed specifications.

\section{Acknowledgements}

This research was supported by the Internal Grant Agency of Mendel University in Brno from the project "Intangible assets as sources and new possibilities for their recognition and disclosure".

\section{REFERENCES}

ABOODY, D., KASZNIK, R. and WILLIAMS, M. 2000. Purchase versus pooling in stock for-stock acquisitions: Why do firms care? Journal of Accounting and Economics, 29(3): 261-286.

AMIR, E., KIRSCHENHEITER, M. and WILLARD, K. 1997. The Valuation of Deferred Taxes. Contemporary Accounting Research, 14(4): 597-622.

BAUMAN, M. P. and SHAW, K. W. 2016. Balance sheet classification and the valuation of deferred taxes. Research in Accounting Regulation, 28(2): 77-85.

BAUMAN, M. P. and SHAW, K. W. 2018. Value relevance of customer-related intangible assets. Research in Accounting Regulation, 30(2): 95-102.

CIPRIAN, G. G., VALENTIN, R., GRIGORE, A. M. and LUCIA, V. M. 2012. From visible to hidden intangible assets. Procedia - Social and Behavioral Sciences, 62: 682-688.

DARROUGH, M. N., GULER, L. and WANG, P. 2014. Goodwill Impairment Losses and CEO Compensation. Journal of Accounting, Auditing \& Finance, 29(4): 435-463.

DUNSE, N. A., HUTCHINSON, N. E. and GOODACRE, A. 2004. Trade related valuations and the treatment of goodwill. Journal of property investment \& finance, 22(3): 236-258.

EDVINSSON, L. 2000. Some perspectives on intangibles and intellectual capital 2000. Journal of intellectual capital, 1(1): 12-16.

FILIP, A., JEANJEAN, T. and PAUGAM, L. 2015. Using Real Activities to Avoid Goodwill Impairment Losses: Evidence and Effect on Future Performance. Journal of Business Finance \& Accounting, 42(3-4): 515-554.

FELTHAM, G. A. and OHLSON, J. A. 1995. Valuation and Clean Surplus Accounting for Operating and Financial Activities. Contemporary Accounting Research, 11(2): 689-731.

HENNING, S. L., LEWIS, B. L. and SHAW, W. H. 2000. Valuation of the Components of Purchased Goodwill. Journal of Accounting Research, 38(2): 375-386.

CHAUVIN, K. W. and HIRSCHEY, M. 1994. Goodwill, profitability, and the market value of the firm. Journal of Accounting and Public Policy, 13(2): 159-180.

CHOI, W. W., KWON, S. S. and LOBO, G. J. 2000. Market Valuation of Intangible Assets. Journal of Business Research, 49(1): 35-45.

JENNINGS, R., ROBINSON, J., THOMPSON, R. B. and DUVALL, L. 1996. The Relation Between Accounting Goodwill Numbers and Equity Values. Journal of Business Finance \& Accounting, 23(4): 513-533. 
JERMAN, M., KAVČIČ, S. and KAVČIČ, B. 2010. The Significance of Intangibles: A Comparative Analysis Between Croatia, Slovenia, Czech Republic, Germany and the USA. Economic Research-Ekonomska Istraživanja, 23(2): 60-69.

KIRK, R. J. 2009. Asset valuation. In: IFRS: A Quick Reference Guide. Elsevier, pp. 88-127.

KOGUT, B. and ZANDER, U. 1996. What Firms Do? Coordination, Identity, and Learning. Organization Science, 7(5): 502-518.

KYLÄHEIKO, K., JANTUNEN, A., PUUMALAINEN, K., SAARENKETO, S. and TUPPURA, A. 2011. Innovation and internationalization as growth strategies: The role of technological capabilities and appropriability. International Business Review, 20(5): 508-520.

LAUX, R. C. 2013. The Association between Deferred Tax Assets and Liabilities and Future Tax Payments. The Accounting Review, 88(4): 1357-1383.

MCCARTHY, M. G. and SCHNEIDER, D. K. 1995. Market Perception of Goodwill: Some Empirical Evidence. Accounting and Business Research, 26(1): 69-81.

MERCER, Z. C. and CROW, M. R. 2002. Goodwill valuation under SFAS 142. The CPA Journal, 72(2): 22-29.

MERITUM PROJECT. 2002. Guidelines for Managing and Reporting on Intangibles - Intellectual Capital Report. European Commission. Available at: http://www.urjc.es/innotec/tools/MERITUM\%20 Guidelines.pdf [Accessed: 2019, December 29].

OSINSKI, M., SELIG, P. M., MATOS, F. and ROMAN, D. J. 2017. Methods of evaluation of intangible assets and intellectual capital. Journal of Intellectual Capital, 18(3): 470-485.

NEVADO, D. and LOPEZ, V. R. 2006. El Capital Intelectual, Valoracion y evaluacion. Madrid: ScPerson Educacion.

NOLAN, A. 2011. New sources of growth: intangible assets OECD. Available at: https://www.oecd.org/ sti/50498841.pdf [Accessed: 2019, December 29].

SHALEV, R., ZHANG, I. X. and ZHANG, Y. 2013. CEO Compensation and Fair Value Accounting: Evidence from Purchase Price Allocation. Journal of Accounting Research, 51(4): 819-854.

SPENDER, J.-C. and GRANT, R. M. 1996. Knowledge and the firm: Overview. Strategic Management Journal, 17(S2): 5-9.

SUN, L. 2016. Managerial ability and goodwill impairment. Advances in Accounting, 32: 42-51.

TEECE, D., PISANO, G. and SHUEN, A. 1998. Dynamic capabilities and strategic management. Strategic Management Journal, 18(7): 509-533.

TSAI, C.-F., LU, Y.-H. HUNG, Y.-C. and YEN, D. C. 2016. Intangible assets evaluation: The machine learning perspective. Neurocomputing, 175(3): 110-120.

VERARDI, V. and CROUX, C. 2018. Robust Regression in Stata. The Stata Journal: Promoting communications on statistics and Stata, 9(3): 439-453.

XIANGXI, T. 2017. The Transformation from Specialized Accounting to General Accounting: A Review of Intangible Accounting Research in Recent Ten Years. School of Accounting, Zhongnan University of Economics and Law.

ZELENKA, V. 2006. Goodwill: principles of corporate reporting [in Czech: Goodwill: vykazování $v$ podniku]. $1^{\text {st }}$ Edition. Praha: Ekopress.

\section{LIST OF ABBREVIATIONS}

Variables Definition

PRICE Share price calculated as market capitalization/equity

NFA Net financial assets

NOA Net operating assets

Goodwill Reported goodwill

R \& D C Costs for science and research

ROA Return on assets

ROE Return on equity 


\section{APPENDIX}

Appendix A: VII: Data cleaning

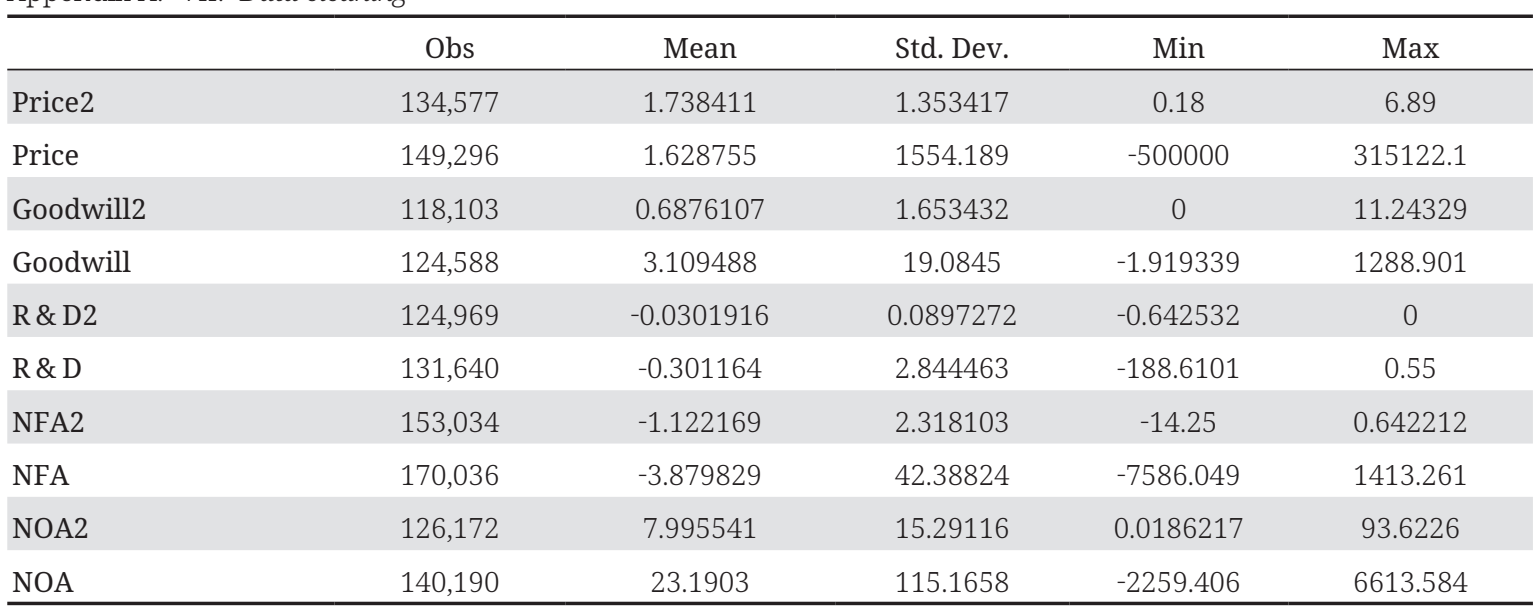

Price 2 - less than 5\%, Price - more than 95\%, etc. 
